\title{
Perspectives and Challenges Regarding Brazilian Policies for Research and Postgraduate Studies in Psychology
}

\author{
Perspectivas e Desafios das Políticas Brasileiras para Pesquisa e Pós-graduação \\ em Psicologia
}

\author{
Raquel Souza Lobo Guzzo ${ }^{a}$, Maria Beatriz Martins Linhares ${ }^{b}$, Maycoln Leôni Martins Teodoro $^{c}$ \\ \& Sílvia Helena Koller ${ }^{\mathrm{d}}$ \\ ${ }^{a}$ Pontifícia Universidade Católica de Campinas, Campinas, SP, Brazil, ${ }^{b}$ Universidade de São Paulo, Ribeirão Preto,

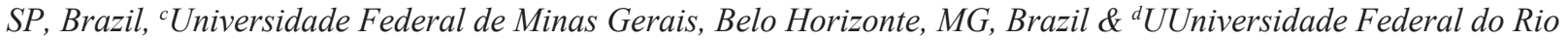 \\ Grande do Sul, Porto Alegre, RS, Brazil, North-West University Vanderbijlpark, Vanderbijlpark, South Africa
}

\begin{abstract}
The National Association of Research and Postgraduate Studies in Psychology (ANPEPP) promotes exchange among researchers to develop and consolidate lines of research, through the discussion of action strategies and decisions that impact Brazilian scientific policy. Themes such as postgraduate research training, national production and the internationalization of knowledge have been the focus of ANPEPP's biennial research and scientific exchange symposia, in forums on Ethics in Research, Scientific Policies and Internationalization. The Scientific Policy Committee (Comissão de Políticas Científicas - CPC) is responsible for each symposium, providing and discussing issues for future goals and plans. Themes identified by the CPC in recent biennia (2010/2012 and 2012/2014) relate to official documents on educational policies (National Education Plan - 2010-2020; National Postgraduate Plan - 2010/2020) and their impact on Brazilian postgraduate programs and the production of research in psychology. Recent themes include: encouraging models of scientific production; clarity of the profile of the researcher; and better conditions for the training of scientists for research, technology and innovation. Fulfillment of these actions is essential for the VI National Postgraduate Plan (VI PNPG in Portuguese) goals to take effect and change the research climate of the country. It will do so through improved monitoring of postgraduate programs, adjustment of training curricula for researchers, and internationalization activities. Formulation, development and evaluation of these policies could herald better prospects for a fair and qualitative growth in Brazilian psychology. Keywords: Scientific Policies, Postgraduate studies, ANPEPP, National Education Plan.
\end{abstract}

\begin{abstract}
Resumo
A ANPEPP promove intercâmbio entre pesquisadores para desenvolver, consolidar linhas de pesquisa com discussão de estratégias de ação e decisões que impactam as políticas científicas na área. Temas como a formação de recursos humanos para a pesquisa, a produção nacional e a internacionalização do conhecimento têm sido foco de simpósios bienais brasileiros de pesquisa e intercâmbio científico. Esses temas são debatidos nos chamados Fóruns sobre Ética na Pesquisa, Políticas Científicas e Internacionalização. A Comissão de Políticas Científica (CPC) tem a responsabilidade de, a cada simpósio, trazer informações sobre problemas e questões para discussão, com um caráter propositivo e, também, apontar e planejar o futuro da área. Os temas identificados pela CPC nos últimos biênios (2010/2012 e 2012/2014) relacionam-se aos documentos oficiais sobre as políticas educacionais (Plano Nacional de Educação 2010/2020 e Plano Nacional de Pós-Graduação - 2010/2020) e seus impactos nos programas brasileiros de pós-graduação e na produção da pesquisa em Psicologia, tais como o incentivo a modelos de produção científica, clareza do perfil do pesquisador e melhores condições para a formação de recursos humanos para a ciência, tecnologia e inovação. É imprescindível o cumprimento das ações propostas para que as metas expressas no VI PNPG possam ser efetivadas e mudem as condições de pesquisa do país, por avaliação e acompanhamento dos programas de Pós-Graduação, por iniciativas de flexibilização dos currículos de formação dos pesquisadores, e por atividades de internacionalização. A participação dos programas e dos pesquisadores na formulação, desenvolvimento e avaliação dessas políticas pode anunciar melhores perspectivas para um crescimento equitativo e qualitativo da produção científica em Psicologia no país. Palavras-chave: Políticas Científicas, Pós-Graduação, ANPEPP, Plano Nacional de Educação.
\end{abstract}

Correspondence concerning this article should be addressed to Sílvia Helena Koller, Center for Psychological Studies on At-Risk Populations (CEP-Rua), Institute of Psychology, Federal University of Rio Grande do Sul (UFRGS), Brazil; email: silvia.koller@gmail.com 
In 1988, representatives of Brazilian postgraduate programs in psychology met in Caruaru, state of Pernambuco, for the First Symposium of Research and Scientific Exchange. This event was sponsored by the National Association of Research and Postgraduate Studies in Psychology (ANPEPP). ANPEPP was established in 1983 and promoted its first major event with the goal of reviewing the output and progress of Brazilian psychological research from the previous five years. The expectation was promotion of a more effective exchange between researchers; and to promote the development and consolidation of lines, or areas, of research. This goal led to discussions regarding action strategies, facing challenges, and the structural and functional decisions that have an impact on the scientific policies in the field. Since then, the training of scientists for research, scholarly production, and the internationalization of psychology have been the focus of the Brazilian biennial symposia of of ANPEPP. However, these biennial meetings have had various formats. The different programs of the symposia have ranged from individual presentations, as in Caruaru (ANPEPP, 1988), with the participation of professors from fifteen Brazilian universities, to the most recent version in Bento Gonçalves, state of Rio Grande do Sul (ANPEPP, 2014) with more than 1,300 professors, postdoctoral students, and postgraduate students from far reaches of the country and abroad. Over the diverse symposia, researchers discussed ongoing research, presented results, and planned future collaboration in working groups (WGs). Several round tables were organized with themes related to the evaluation of topics regarding scientific policies fundamental to fulfilling the aim of ANPEPP. Since the 2004 gathering, in Aracruz, state of Espírito Santo (ANPEPP, 2004), discussion forums were included in the program. These forums are privileged spaces for researchers to discuss important themes, such as research ethics in psychology, internationalization, and scientific policies. The main aim of these forums is to outline policies for the future, and supporting and legitimizing actions, for the performance of ANPEPP in the national and international arenas.

The scientific policies forum has been coordinated by the Scientific Policy Committee (CPC), which is comprised of researchers. The CPC aims to support and organize ANPEPP through establishing: a) policies; b) new actions and motions; c) information and explanation of ANPEPP programs; d) updates to the site and newsletter; and e) organization of the biennial forum and proposals. The last item highlights the study of the evaluation model of programs and researchers, to propose alternatives for the development and evaluation agencies (Coordination for the Improvement of Higher Education Personnel CAPES in Portuguese; National Council for Scientific and Technological Development - CNPq in Portuguese).

The aim and character of the CPC has been to advise the Board of ANPEPP and not to deliberate. Thus, in each symposium the CPC draws attention to information on themes, problems and issues for discussion. Therefore, the Committee has a propositional character (for example: improvement of the postgraduate program evaluation process), as well as a role in highlighting and charting the future of the area. Due to the magnitude and complexity of the themes, the Committee has focused on issues that the Board of ANPEPP performs with the programs, such as: a) evaluation of training and production (basically, the evaluation by CAPES); b) evaluation of scientific journals; and c) promotion of research, through both scholarships and grants.

In the last symposium, in Bento Gonçalves, the CPC defined a strategy, with the articulation of this committee with the others of ANPEPP, with a focus on the avoidance of overlapping actions between committees. Another guideline was gathering information from sister areas of knowledge (e.g., social sciences, education, business, anthropology) on the operation of their committees for scientific policies, themes in common, etc. The themes identified by the CPC in the last biennial meetings (2010/2012 and 2012/2014) related to scientific policies in educational policy documents (National Education Plan - 2010/2020 and National Postgraduate Plan $2010 / 2020$ ), as well as the impact of these policies on Brazilian postgraduate programs and on the production of psychological research. The themes were organized into such categories as: a) the training of human resources for research; b) scientific production; c) interdisciplinarity; d) the evaluation of psychological programs and journals; and e) the internationalization of Brazilian science and training.

\section{National policies for research in Psychology}

The scientific research that is mostly carried out in universities has been governed by a National Postgraduate Plan (PNPG in Portuguese $)^{1}$, which in turn is part of a National Education Plan (PNE) ${ }^{2}$. In this plan, all educational levels, methods and steps of the education process are regulated through objective guidelines and goals following specific strategies for their consolidation. In addition to the national plans that constitute general guidelines, specific agendas are formulated for the realization of research activities.

The idea of educational planning has always been controversial and related to other political and economic policy dimensions. Thus, the National Education Plans constituted important guidelines for education at all levels, covering multiple dimensions, from the enrollment of students to teacher training, research and infrastructure (Queiroz \& Gomes, 2011).

Brazil has had six National Graduate Plans. The first in the 1970s (I PNPG - 1975/1979), the second (II PNPG - 1982-1985), the third (III PNPG - 1986/1989), the fourth (IV PNPG -1990 / 2000), the fifth (V PNPG 2001/2010) and the last (VI PNPG - 2011/2020).

The first Brazilian PNE of 1937 remained without effect until 1962 due to the country not being organized in terms of educational planning. In this year the I National Education Plan was instituted, with quantitative goals to be achieved over a period of eight years, directed by the first Law of Directives and Bases of National Education (Azanha, 1993). It has only been since 2001 that the National Education Plans have been put into effect every ten years. 
The universalization of access and service at all educational levels are mentioned in the national plan; however, they have not yet been implemented, which indirectly makes scientific production difficult at the top of this system. The future of Brazilian scientific production is configured to define its trajectory, without succumbing to a situation that is rapidly configured and reconfigured at the national and international level.

The prospects for Brazilian research and postgraduate studies, according to Gazzola and Fenati (2010), are related to how public policies affecting research and education can impact people's lives and society. This position attaches importance to scientific production, which should construct a trajectory that moves from a modest contribution to one of more international prominence. For this, it is necessary for scientific research to be publicly appropriated and for the goals be debated and be known.

In Brazil, the National Postgraduate Plan (PNPG - 20112020; Brazil, 2010), proposed by the Coordination for the Improvement of Higher Education Personnel (CAPES) is organized according to the following main points: a) the expansion and improvement of the quality of the graduate educational system; $b$ ) the creation of a national research agenda and its association with the postgraduate programs; c) the improvement of the evaluation system; d) the implementation of multi and interdisciplinary postgraduate programs and relevant research themes; and e) support for the elementary education system and other levels of education, especially at the high school level.

The PNPG 2011-2020 included a historical overview of the previous plans for the improvement of the postgraduate system in Brazil. It introduced twenty proposals to expand and improve the quality of the educational system in Brazil. The twelfth point was a proposal to increase the admission of students to the higher education course to $50 \%$, and the percentage of students aged 18-24 years in this population to $30 \%$. The thirteenth point suggested that, to raise the quality of the university education system, the amount of qualified teachers with master's or doctoral degrees should be expanded to $70 \%$, with at least $35 \%$ of them holding doctorates. The fourteenth point recommended gradually increasing admissions into the stricto sensu postgraduate programs in order to achieve the training of 69,000 master's and 25,000 doctoral degrees.

In the fifth chapter, the evaluation process of the postgraduate programs is especially focused on the following main areas: a) the evaluation process should be regular and periodic, and performed by evaluators selected from the academic and scientific communities, with the approval of the higher committee of CAPES; b) programs are classified on a scale of 3 to 5 , however, can also be classified as 6 or 7 points, depending on their international efficacy profile; and c) the consequences of the evaluation process are directly associated with the financial support policies offered to the programs by the federal agencies. The evaluation system applies criteria that take into account whether the postgraduate program offers only the master's educational level or whether the program also includes doctoral studies. Regarding item $b$, this clarifies that the classification is based on various topics, such as: proposal of the program, the students, profiles and results of researchers, research projects, publications and translation of knowledge into practice. Therefore, programs are classified according to their academic and scientific qualities.

In the context of the current PNPD guidelines, four aspects can be highlighted to better understand the scientific policies in Brazil that address postgraduate programs: a) innovation; b) internationalization; c) asymmetries; and d) interdisciplinary research themes. These aspects will be discussed below in the context of the area of psychology.

Regarding the first aspect, innovation is focused on original projects, which can add new methodologies, instruments and procedures, offer new solutions to old problems or discover new relationships between different fields of knowledge. Innovation can advance the sciences to work in frontier zones of knowledge, promoting special advances. Researchers, working in a specific field, have the greatest competence to evaluate questions and gaps in the scientific literature within their chosen field. Because of this specificity, they can appreciate and anticipate innovative research findings. Therefore, they are best able to evaluate the aspects of innovation and the potential contributions of research projects. The evaluators of scientific articles, projects, dissertations and theses are especially chosen, to raise the quality of output in different areas of knowledge.

In relation to the second aspect, internationalization policies are crucial for postgraduate programs, including a) training missions for future researchers; and b) publication of their findings in international journals. In the evaluation system of CAPES, when postgraduate programs reach the highest levels with scores of 6 or 7 , they are deemed programs of excellent performance and international profile. The rankings range from 2 to 7 , where 2 means disaccreditation and 5 is on the cusp of 6 or 7. The interactions of the researchers and publications in collaboration with their international partners, as well as the attractiveness of the postgraduate program for foreign students, are important themes in the international profile of a Brazilian postgraduate program. However, despite Brazil having increased the number of its scientific publications in international databases, the impact factor, visibility, and citation counts of these publications is still modest in the overall scenario.

We now consider the third aspect, in which geographic, economic, social and regional asymmetries are reflected in Brazil's psychological output. The problems of research, the unavailability of financing from federal and regional agencies, and the requirement for practical and urgent solutions to Brazilian social problems still generate regional asymmetries. These asymmetries can be reduced through 
scientific policies that support groups and institutions with original ideas, as well as researchers addressing unique problems. Networks and associated laboratories can contribute, along with different groups of researchers and higher education institutions, to the dissemination of knowledge and experience in different areas.

Research funding agencies have presented initiatives to redress regional asymmetries in Brazil. One example: programs and grants are available to foster collaboration between researchers from different universities with different research goals as well as different resources. In acknowledgement of the variability of scientific output throughout the nation of Brazil, the National Council for Scientific and Technological Development (MCTI/CNPq) has established funding that assists certain regions.

Regarding the fourth aspect, interdisciplinary themes are considered challenges within the field of psychology. As a human science, psychological research addresses universal psychosocial issues. In Brazil, research in this field addresses: violence (in families, in communities and urban); health problems (mental, morbidity, and mortality in early childhood); shortcomings of the educational system in promoting learning and child development, as well as inefficient public policies. In addition, neurosciences, epigenetics and human development are sister areas that share the theoretical framework and theories of psychology. While the PNPG highlighted other examples of interdisciplinary themes in different areas, the take-home point was that different scientific fields should tackle the asymmetries that are preventing the disciplines from being connected. An additional strategy of integration concerns movement toward the frontier of science and the transfer of knowledge through integration.

Psychological science in Brazil needs an increased amount of financial support for projects with academic merit, as they are rarely prioritized for funding by Brazilian science agencies. Psychological science should receive financial support to expand its development in Brazil, focusing on the basic psychological processes, evaluations and applied interventions. There is funding for other areas-i.e., supporting studies on the construction of roads, bridges and power plants-work aimed at improving the quality of life on the planet. Psychological science is an area that mostly focuses on humans and their multiple relationships. These relationships include their ability to comprehend and intervene in the interactions between people and urban or rural planning, as well as the implications for the ecosystems. Indeed, psychological research contributes to the translation of scientific findings into practice, the promotion of well-being. It involves the integration of its findings into action. After all, if science does not upgrade our quality of life, it is of little or no value to the people.

In short, the PNPG 2010/2020 aims to have an impact on the organization of researcher training programs, through curricular innovations, diversity and multi- transdisciplinarity. The mission is to consolidate the postgraduate scenario, to overcome regional inequalities, and to promote interinstitutional adoption programs, with indicators of solidarity, strategic international consortia, and the development of centers of excellence.

\section{Visibility of Academic Production - macro and micro editorial problems}

In recent decades Brazil has intensified the adoption of policies in science and technology that are not unique to the country. According to Velho (2011), the origin of this system comes from the countries that won World War II, mainly the United States and the United Kingdom. Since then, the so-called normative-institutional model has been implemented in different countries as a unique way to manage and evaluate scientific production. This policy was further developed in the 1990s with the adoption of measures, such as the evaluation of postgraduate program professors-researchers (Godoi \& Xavier, 2012).

The evaluation of Brazilian scientific and technological production gained another chapter with the publication of the VI National Postgraduate Plan - PNPG (MEC/ CAPES, 2010), as explained in the previous section. This publication showed that Brazil has been consolidating the postgraduate system, and has increased its quality, as per various indices. Among these, there has been a considerable increase in the number of new researchers trained over a shorter period of time than 20 years ago and, in the same way, an increase in the number of articles, chapters and books authored by Brazilian scholars. In a way, this increase was induced by the evaluation policies of the past, which attached weight to the activities and production of the researcher.

In addition to government inducements for publication, there has also been a steady increase in the number of postgraduate programs. In psychology, for example, 73 master's (two of these professional) and 47 doctorate courses were evaluated over the last triennium (2010-2012; MEC/ CAPES, 2013). The steady increase in publications is a consequence of this growth. With regard to articles, 7,373 manuscripts were published in the 2010-2012 triennium, $53.4 \%$ more than the previous triennium $(4,807$ in the period 2007-2009), which produced a mean of 2.5 articles/year per researcher for the period (Bastos, Andery, \& Trindade, 2013).

Parallel to the increase in production has been an increase in the number of scientific journals evaluated by Qualis ${ }^{3}$. The CAPES triennium report (Bastos, Andery, \& Trindade, 2013) points out that over the previous three years there was an increase of $9.3 \%$ in the number of national journals in psychology. In 2010, 205 were classified as scientific

The Qualis periodical is a hierarchical classification system of journals, divided into seven levels: A1, A2, B1, B2, B3, B4 and B5. In the current form, the highest classification is achieved through a set of requirements that range from formal criteria such as the regularity of production to the indexing sites of the journal. 
journals in Brazil by Qualis, a number that increased to 225 by the end of 2012. The growth, however, was higher for the group of national journals in related areas $(33 \%$, totaling 1,335), for international journals of psychology (40\%, totaling 351), and for international journals in related areas (39\%, totaling 869), suggesting that Brazilian authors are diversifying their publication output.

Considering the indexing criteria for the classification of psychology journals in Qualis, as A1 (ISI and PsycInfo); A2 (ISI or PsycInfo, Scopus and Scielo); and B1 (PsycInfo or Scopus or SciELO; or in four of the following: Clase, Latindex, Lilacs, Psicodoc, Pascal, or Redalyc), a clear difference can be seen between the classification of national journals in psychology and the others. While international journals are mostly classified as A1, A2 and B1, the majority of national journals are classified in the $\mathrm{B} 2$ and $\mathrm{C}$ categories. The classification criteria adopted by Qualis implies a circular logic that to be good the journal must be indexed and that by being indexed it is good ${ }^{4}$. However, regardless of this discussion, it is clear, from the metric criteria adopted, that the less indexing the journal has, the lower is the chance of an article in the journal being encountered by the reader. As a large number of journals are classified below B1, we can infer that many Brazilian publications will not be found in electronic searches, thus reducing the impact ${ }^{5}$ of the studies, and the output of the postgraduate programs.

Following this reasoning, the question remains: why are the national journals not indexed? By analyzing the set of journals applying for indexation in the SciELO database, Rego (2014) responded as follows:

"After successive and varied opportunities to closely examine the set of journals submitted, we found that the majority of those applying are visibly weak and immature. They can vary in terms of origin, format, editorial mission, indexing sources etc., however, they are similar in one very disturbing respect: many seem to have been organized in haste, driven by the urgency to meet the numerous demands of the governmental organs and the development agencies. If analyzed together, except for one or two increasingly rare exceptions, the majority seem to be nothing more than vehicles to drain the production of researchers, research centers, universities and colleges of different areas of knowledge and different regions of Brazil.” (pp. 332) Combined with the weakness of the journals highlighted by Rego (2014), other factors responsible for the lack of indexing of Brazilian journals can be cited. The first point refers to the workload of the researcher that, added to the absence of preparation to edit journals, ends up producing delays in the evaluation of the manuscripts and publication of the contents. Another issue is the lack of physical structure

\footnotetext{
The idea of this argument was previously presented by Ortiz (2008) referring to the impact factor, in which the article is good because it was cited and is cited because it is good.

Here, impact means the scope of the results of the studies in the research groups.
}

and secretarial help, which results in overloading the editors themselves. There has also been difficulty in getting qualified reviewers, often due to the overload of activities to which professors are submitted. To give an idea of the magnitude of this task, if we consider the national journals in psychology, and we assume two issues output per year, and within each issue about seven articles, then the 225 national psychological journals would be publishing at least 3,159 articles per year. If we continue this reasoning and consider that each approved article (excluding the rejected manuscripts) is read by two reviewers, this would entail a need for 6,300 reviewers per year.

Another important factor for the national journals is that the increase in Brazilian productivity is congesting the major journals. In an analysis of academic productivism, Godoi and Xavier (2011) pointed out that one consequence of the quantitative evaluation system is the production of studies with little or no relevance, which give origin to junk papers, characterized by articles that do not add value to the scientific knowledge, which could even justify the low rates of citation and self-citation among Brazilian authors. Going beyond this analysis, Rego (2014) stressed that the proliferation of the number of low quality academic journals has resulted in the congestion of the more prestigious journals and, after submissions are refused by these: publishing in journals with lower or no editorial requirements. These articles will soon be forgotten, however, they will fulfill their main role: to gain points for the evaluation of the institution by the funding agencies. The profusion of these articles has even fueled the creation of journals by "predatory publishers," characterized by editors who exploit the need of the researcher to publish to create international journals with low publication requirements, rapid editorial proceeding, and high financial costs for publication (Wood Junior, 2013).

\section{Prospects}

To propose new prospects for the Brazilian Postgraduate Program is undoubtedly a task that requires a thorough analysis of broad policy issues. These issues have a direct impact on scientific production, on the training of teachers for higher education and research, and on the financial resources for infrastructure, development and technological innovation. These issues address the incentive of scientific production models, clarity of the researcher profile, and better conditions for the training of researchers for science, technology and innovation.

The development of the Brazilian Postgraduate Program was conceived by the federal government and was not the result of a spontaneous growth process impacting the number of researchers and their research projects. In addition to its regulatory functions, which included modernization of Brazilian higher education as well as expansion of postgraduate programs, the efforts of the I PNPG gave birth to today's Postgraduate Program, which 
constitutes a privileged space of scientific exploration (Cruz, 2010).

Nonetheless, we are obligated to fulfill our obligations, especially to the regulatory agencies, such as CAPES, so the goals expressed in the VI PNPG can take effect and change the research conditions of the country. This change needs to include greater monitoring of postgraduate programs, especially those that receive federal grants. We need greater flexibility in the training curricula of researchers, and the activities of internationalization. The expansion of programs alone, focusing on greater regional distribution, does not ensure the functioning of excellence. A consolidated effort and involvement by researchers in the design, development and evaluation of these policies may herald better prospects for fair and qualitative growth, and a brighter future for Brazilian psychology.

\section{References}

ANPEPP (1988). Anais do I Simpósio Brasileiro de Pesquisa e Intercâmbio Científico da Psicologia [Proceedings of the First Brazilian Symposium on Scientific Research and Psychology]. Exchange. Caruaru, PE: Author.

ANPEPP (2004). Anais do X Simpósio Brasileiro de Pesquisa e Intercâmbio Cientifico da Psicologia [Proceedings of the 10th Brazilian Symposium on Scientific Research and Psychology Exchange]. Aracruz, ES: Author.

ANPEPP (2014). Anais do XV Simpósio Brasileiro de Pesquisa e Intercâmbio Cientifico da Psicologia [Proceedings of the 15th Brazilian Symposium on Scientific Research and Psychology Exchange]. Bento Gonçalves, RS: Author.

Azanha, J.M.P. (1993). Políticas e planos de educação no Brasil: Alguns pontos para a reflexão [Education policies and plans in Brazil: Some points for reflection]. Cadernos de Pesquisa, $85,70-78$.

Bastos, A. V. B., Andery, M. A. P. A., \& Trindade, Z. A. (2013). Documento de Área: Psicologia [CAPES Evaluation Report: Psychology]. Brasília, DF: CAPES. Retrieved from http://www.capes.gov.br/component/content/ article?id=4681:psicologia

Brasil. Ministério da Educação. Coordenação de Aperfeiçoamento de Pessoal de Nível Superior (2010). Plano Nacional de Pós-Graduação - PNPG 2011-2020 /Coordenação de Pessoal de Nivel Superior [National Education Plan - 2010/2020 and National Postgraduate Plan - 2010 / 2020]. Brasília, DF: Author

Cruz, C. H. B. (2010). Ciência, tecnologia e inovação no Brasil: Desafios para o período de 2011 a 2015 [Science, technology and innovation in Brazil: Challenges for the period 20112015]. Interesse Nacional, 3(10). Retrieved from http:// interessenacional.uol.com.br/index.php/edicoes-revista/ ciencia-tecnologia-e-inovacao-no-brasil-desafios-para-operiodo-2011-a-2015/

Gazzola, A. L. A., \& Fenati, R. A. (2010). Pós-graduação brasileira no horizonte de 2020 [Brazilian Postgraduate in Horizont 2020]. In Brasil, Ministério da Educação,
Coordenação de Aperfeiçoamento Pessoal de Nível Superior (Ed.), Plano Nacional de Pós-Graduação - 2011-2020 (Vol. 2, pp. 7-16). Coordenação de Pessoal de Nível Superior. Brasília, DF: CAPES.

Godoi, C. K., \& Xavier, W. G. (2012). O produtivismo e suas anomalias [Productivism and its anomalies]. Cadernos EBAPE.BR, 10(2), 456-465.

Ortiz, R. (2008). A diversidade dos sotaques: $O$ inglês e as ciências sociais [The diversity of accents: English and social sciences]. São Paulo: Brasiliense.

Queiroz, A., \& Gomes, L. (2011). Planejamento Educacional no Brasil [Educational Planning in Brazil]. FNE - Fórum Nacional de Educação. Brasília, DF: MEC.

Rego, T. C. (2014). Produtivismo, pesquisa e comunicação científica: Entre o veneno e o remédio [Productivism, research and scholarly communication: Between poison and medicine]. Educação e Pesquisa, 40(2), 325-346. Retrieved from http:// dx.doi.org/10.1590/S1517-97022014061843

Velho, L. (2011). Conceitos de ciência e a política científica, tecnológica e de inovação [The concept of Science, and the Science, technology and innovation Policy]. Sociologias, 13(26), 128-153.

Wood Júnior, T. (2013). Pseudoacademia. Carta Capital. Retrieved from http://www.cartacapital.com.br/revista/763/ pseudoacademia-178.html.
Received: September 02, 2014 Reviewed: March 03, 2015 Accepted: May 25, 2015 